\title{
Overtraining Does Not Induce Oxidative Stress and Inflammation in Blood and Heart of Rats
}

\author{
D. STANOJEVIC ${ }^{1}$, V. JAKOVLJEVIC ${ }^{2}$, N. BARUDZIC ${ }^{2}$, V. ZIVKOVIC ${ }^{2}$, I. SREJOVIC ${ }^{2}$, \\ K. PAREZANOVIC ILIC ${ }^{2}$, D. CUBRILO ${ }^{3}$, Z. AHMETOVIC ${ }^{3}$, D. PERIC ${ }^{3}$, M. ROSIC ${ }^{4}$, \\ D. RADOVANOVIC ${ }^{5}$, D. DJORDJEVIC ${ }^{2}$
}

${ }^{1}$ Special Hospital Merkur, Vrnjacka Banja, Serbia, ${ }^{2}$ Department of Physiology, Faculty of Medical Sciences, University of Kragujevac, Kragujevac, Serbia, ${ }^{3}$ Faculty for Sport and Tourism, Educons University, Novi Sad, Serbia, ${ }^{4}$ Institute of Cardiovascular Disease, Sremska Kamenica, Novi Sad, Serbia, ${ }^{5}$ Department of Physiology, Faculty of Sport and Physical Education, University of Nis, Nis, Serbia

Received April 19, 2015

Accepted August 28, 2015

On-line November 24, 2015

\begin{abstract}
Summary
The aim of our research was to evaluate the changes in levels of cytokines and redox state parameters in blood and isolated heart of rats subjected to different swimming protocols. Rats were divided into 3 groups: 1) controls, 2) moderately trained rats that during all 12 weeks swam $1 \mathrm{~h} /$ day, 5 days/week, and 3 ) overtrained rats that in $10^{\text {th }}$ week swam twice, $11^{\text {th }}$ week 3 times, and in $12^{\text {th }}$ week 4 times a day for $1 \mathrm{~h}$. After sacrificing, blood from jugular vein was collected, and the heart excised and perfused on a Langendorff apparatus. Samples of the coronary effluent were collected during coronary autoregulation. Levels of superoxide anion radical $\left(\mathrm{O}_{2}{ }^{-}\right)$, hydrogen peroxide $\left(\mathrm{H}_{2} \mathrm{O}_{2}\right)$, nitric oxide (NO) and thiobarbituric acid reactive substances (TBARS) were measured in plasma and coronary effluent, while reduced glutathione (GSH), activities of superoxide dismutase (SOD) and catalase (CAT) were measured in erythrocytes. Venous blood was also used for interleukin 6 (IL-6) and tumor necrosis factor alpha (TNF-a) determination. Moderate training protocol induced the decrease of TBARS in plasma, while both training protocols induced the decrease of $\mathrm{O}_{2}^{-}$and $\mathrm{H}_{2} \mathrm{O}_{2}$ in coronary effluent. There was no significant difference in levels of cytokines between groups. The results of study add evidence about beneficial effects of moderate-intensity training on blood and cardiac redox state of rats, and furthermore, shows that exercising frequently, if the intensity stays within moderate range, may not have detrimental effects.
\end{abstract}

\section{Key words}

Overtraining • Redox state $\bullet$ Cytokines $\bullet$ Swimming $\bullet$ Isolated rat heart $\bullet$ Frequent training

\section{Corresponding author}

V. Jakovljevic, Faculty of Medical Sciences, University of Kragujevac, Svetozara Markovica 69, 34000 Kragujevac, Serbia. Fax: +381343068 00/ext 112. E-mail: drvladakgbg@yahoo.com

\section{Introduction}

According to the contemporary scientific data, in a well-planned and programmed training process, the training load increases stepwise and the periods of rest between the exercise bouts are sufficiently long to ensure regeneration of the muscle functions, but still short enough to not allow the regression of supercompensation (Seene et al. 2004). Every athletic training program includes a component of repetitive overloading, but with an inadequate recovery time, such overloading may produce undesired effects, such as chronic fatigue and the absence of performance improvement (Kadaja et al. 2010), i.e. the overtraining syndrome (OTS). Since it is not ethical to train athletes in such a manner that they develop OTS, in order to explore the etiology and symptoms of this phenomenon, animal overtraining models have been developed (Hohl et al. 2009, Pereira et 
al. 2012). Animal (rat) models often allow for more invasive, extensive, and homogenous experimental designs than human models. These rat-based exercise studies may provide more information and help to elucidate the effects of different training regimes on numerous body structures and functions.

The aim of our research was to evaluate the changes in levels of cytokines and redox state parameters in blood and isolated heart of rats subjected to different swimming protocols during 12 weeks. We hypothesized that moderate intensity swimming training (60 min of daily swimming, 5 times a week), which is the most commonly used rat swimming protocol in exercise physiology studies, would not induce significant rise of inflammatory markers in rats' blood, but would induce upregulation of rats' endogenous antioxidative defence. On the other side, we hypothesized that increasing frequency of trainings and decreasing recovery time between trainings may lead towards the rise of levels of inflammatory markers, as well as undesirable systemic and cardiac redox state changes. We based our assumptions on results of previously published studies that used similar rat exercise protocols (Ogonovszky et al. 2005, Zoppi and Macedo 2008, Lira et al. 2010, Dong et al. 2011, Ferraresso et al. 2012, Gholamnezhad et al. 2013), and showed existence of relationship between OTS, oxidative stress and inflammation in different tissues.

\section{Materials and Methods}

\section{Ethical approval}

The study was performed in the cardiovascular laboratory of the Faculty of Medical Sciences, University of Kragujevac, Serbia. It was approved by Ethical committee of the Faculty, and performed according to the Faculty's rules for the welfare of laboratory animals, which are in consent with Good laboratory practice and European Council Directive (86/609/EEC).

\section{Subjects}

Twenty one Wistar albino rat (females, eight weeks old, body weight $200 \pm 50 \mathrm{~g}$ ) was subjected to the study's protocol. The sample size was calculated based on previously published study (Ferraresso et al. 2012), using an appropriate computer program (Faul et al. 2007). Rats were housed in cages (3 rats per cage) in a room where temperature was maintained on $25^{\circ} \mathrm{C}$, with $12 \mathrm{~h}$ of light daily. They consumed commercial rat food (20\% protein rat food, Veterinary institute Subotica, Serbia) and water ad libitum.

Table 1. Overtraining swimming protocol.

\begin{tabular}{lccccc}
\hline $\begin{array}{l}\text { Week } \\
\text { No. }\end{array}$ & $\begin{array}{c}\text { Training } \\
\text { phase }\end{array}$ & $\begin{array}{c}\text { Swimming } \\
\text { duration }\end{array}$ & $\begin{array}{c}\text { Daily number of } \\
\text { training sessions }\end{array}$ & $\begin{array}{c}\text { Recovery between } \\
\text { training sessions }\end{array}$ & $\begin{array}{c}\text { Physical capacity } \\
\text { test }\end{array}$ \\
\hline 1 & AW & $5-15 \mathrm{~min}$ & 1 & $24 \mathrm{~h}$ & $\mathrm{~T} 1$ \\
2 & AT1 & $20 \mathrm{~min}$ & 1 & $24 \mathrm{~h}$ & $/$ \\
3 & AT1 & $30 \mathrm{~min}$ & 1 & $24 \mathrm{~h}$ & $/$ \\
4 & AT1 & $45 \mathrm{~min}$ & 1 & $24 \mathrm{~h}$ & T2 \\
5 & AT1 & $60 \mathrm{~min}$ & 1 & $24 \mathrm{~h}$ & $/$ \\
6 & AT2 & $60 \mathrm{~min}$ & 1 & $24 \mathrm{~h}$ & $/$ \\
7 & AT2 & $60 \mathrm{~min}$ & 1 & $24 \mathrm{~h}$ & $\mathrm{~T}$ \\
9 & AT2 & $60 \mathrm{~min}$ & 1 & $24 \mathrm{~h}$ & $\mathrm{~h}$ \\
10 & AT2 & $60 \mathrm{~min}$ & 2 & $4 \mathrm{~h}$ & $\mathrm{~T} 4$ \\
\hline 12 & T2x & $60 \mathrm{~min}$ & 3 & $2 \mathrm{~h}$ & $\mathrm{~T}$ \\
\hline
\end{tabular}

AW - adaptation to water, AT1 and AT2 - adaptive training phases 1 and 2, T2x, T3x, and T4x - overtraining phase in which daily training frequency is increased to two, three, and four times.

\section{Exercise training protocol}

Rats were divided into three groups: control $(\mathrm{C})$, moderately trained (MT) and overtrained (OT) group and subjected to 12 weeks of swimming training according to different training protocols. Overtrained rats swam according to the protocol in Table 1, which represents 
previously developed overtraining animal model (Hohl et al. 2009), performed in water instead of treadmill (Stojanovic Tosic et al. 2015). It is based on increasing frequency of trainings, decreasing recovery time between trainings, and increasing total volume of training. Rats chosen for the moderately trained group trained according to the protocol in Table 1 until the end of nineth week. Then, they continued to swim once a day for $60 \mathrm{~min}$ until the end of $12^{\text {th }}$ week. Rats from the control group were put in water for $3 \mathrm{~min}$ a day, 5 days a week, all 12 weeks, in order to achieve the water-induced stress effect. Rats swam in a specially constructed swimming pool made of glass $(80 \times 60 \times 100 \mathrm{~cm})$ in which water temperature $\left(34{ }^{\circ} \mathrm{C}\right)$ was maintained by an electric heater, and a pump continuously made waves in order to prevent rats from floating. The swimming was continuously supervised.

\section{Physical capacity test}

During 12 weeks of exercise training program, rats from all three groups were subjected to six endurance swimming tests (schedule of testing is presented in Table 1). Physical capacity tests were performed in order to asses if rats experienced OTS, since the only certain sign of this syndrome is a decrease in performance during competition or training (Meeusen et al. 2013). Every physical capacity test was performed $30-32 \mathrm{~h}$ after the last training session, and 30-32 $\mathrm{h}$ before the next training session. The test was performed with a weight equivalent to $10 \%$ of body weight, which was attached around the waist of each rat using a rubber band (Bocalini et al. 2010). Rats from all groups were individually observed to determine swimming time until exhaustion. Exhaustion was defined as the point when the rat could not swim up to the water surface for $10 \mathrm{~s}$.

\section{Samples preparation and biochemical analyses}

Thirty six hours after the last physical capacity test, after a short-term ether narcosis and premedication with heparin as an anticoagulant, rats were sacrificed by decapitation. Blood for analysis of systemic oxidative stress and inflammation was collected from the jugular vein into Vacutainer test tube containing sodium citrate anticoagulant. Blood was centrifuged to separate plasma and red blood cells (RBCs). Blood samples were analyzed immediately. Following parameters of oxidative stress were measured in these samples: superoxide anion radical $\left(\mathrm{O}_{2}^{-}\right)$, hydrogen peroxide $\left(\mathrm{H}_{2} \mathrm{O}_{2}\right)$, nitrites $\left(\mathrm{NO}_{2}^{-}\right)$as measure of nitric oxide (NO), thiobarbituric acid reactive substances (TBARS), reduced glutathione (GSH), superoxide dismutase (SOD) and catalase (CAT) activity. Levels of cytokines, interleukin 6 (IL-6) and tumor necrosis factor alpha (TNF- $\alpha)$, were also measured in those samples. Biochemical parameters were measured spectrophotometrically (Specord S-600 Analytik Jena).

Immediately after venous blood sampling, after emergency thoracotomy and rapid cardiac arrest by superfusion with ice-cold isotonic saline, the heart was excised, the aorta cannulated and the heart retrogradely perfused on a Langendorff apparatus (Experimetria Ltd, 1062 Budapest, Hungary). The composition of the nonrecirculating Krebs-Henseleit perfusate was as follows (mmol/1): $\mathrm{NaCl} 118, \mathrm{KCI} 4.7, \mathrm{CaCI}_{2} \cdot 2 \mathrm{H}_{2} \mathrm{O} 2.5, \mathrm{MgSO}_{4}$ - $7 \mathrm{H}_{2} \mathrm{O}$ 1.7, $\mathrm{NaHCO}_{3} 25, \mathrm{KH}_{2} \mathrm{PO}_{4}$ 1.2, glucose 11, pyruvate 2 , equilibrated with $95 \% \mathrm{O}_{2}$ plus $5 \% \mathrm{CO}_{2}$ and

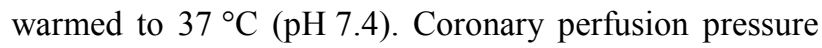
(CPP) was gradually increased (from 40 to $120 \mathrm{~mm} \mathrm{Hg}$ ) in order to establish coronary autoregulation. During each CPP coronary venous effluent was collected for the purpose of determination of levels of prooxidants $\left(\mathrm{O}_{2}\right.$, $\mathrm{H}_{2} \mathrm{O}_{2}, \mathrm{NO}_{2}$, TBARS). These prooxidant analyses were performed using the same methods as when analyzing plasma samples.

\section{Superoxide anion radical determination}

The level of $\mathrm{O}_{2}^{-}$was measured using NBT (nitro blue tetrazolium) reaction in TRIS-buffer combined with plasma samples and read at $530 \mathrm{~nm}$ (Auclair and Voisin 1985).

\section{Hydrogen peroxide determination}

The protocol for measurement of $\mathrm{H}_{2} \mathrm{O}_{2}$ is based on oxidation of phenol red in the presence of horseradish peroxidase (Pick and Keisari 1980). $200 \mu \mathrm{l}$ of plasma with $800 \mu \mathrm{l}$ PRS (Phenol Red Solution) and $10 \mu \mathrm{l}$ POD (Horseradish Peroxidase) were combined (1:20). The level of $\mathrm{H}_{2} \mathrm{O}_{2}$ was measured at $610 \mathrm{~nm}$.

\section{Nitric oxide determination}

NO decomposes rapidly to form stable metabolite nitrite/nitrate products. $\mathrm{NO}_{2}^{-}$was determined as an index of nitric oxide production with Griess reagent (Green et al. 1982). $0.1 \mathrm{ml} \mathrm{3N} \mathrm{PCA} \mathrm{(perchloride} \mathrm{acid),}$ $0.4 \mathrm{ml} 20 \mathrm{mM}$ EDTA (ethylenediaminetetraacetic acid) and $0.2 \mathrm{ml}$ plasma were put on ice for $15 \mathrm{~min}$, then centrifuged $15 \mathrm{~min}$ at $6000 \mathrm{rpm}$. After pouring off the supernatant, $220 \mu \mathrm{l} \quad \mathrm{K}_{2} \mathrm{CO}_{3}$ was added. $\mathrm{NO}_{2}{ }^{-}$was measured at $550 \mathrm{~nm}$. Distilled water was used as a blank probe. 


\section{Thiobarbituric acid reactive substances}

The degree of lipid peroxidation in plasma was estimated by measuring TBARS using $1 \%$ TBA (thiobarbituric acid) in $0.05 \mathrm{NaOH}$, incubated with plasma at $100{ }^{\circ} \mathrm{C}$ for $15 \mathrm{~min}$ and read at $530 \mathrm{~nm}$. Distilled water was used as a blank probe. TBA extract was obtained by combining $0.8 \mathrm{ml}$ plasma and $0.4 \mathrm{ml}$ TCA (trichloro acetic acid), then samples were put on ice for $10 \mathrm{~min}$, and centrifuged for $15 \mathrm{~min}$ at $6000 \mathrm{rpm}$. This method was described previously (Ohkawa et al. 1979).

\section{Determination of antioxidant enzymes}

Isolated RBCs were washed three times with three volumes of ice-cold $0.9 \mathrm{mmol} / \mathrm{l} \mathrm{NaCl}$ and hemolysates containing about $50 \mathrm{~g} \mathrm{Hb} / \mathrm{l}$ (McCord and Fridovich 1969), were used for the determination of CAT activity. CAT activity was determined according to Beutler (1982). Lysates were diluted with distilled water $(1: 7 \mathrm{v} / \mathrm{v})$ and treated with chloroform-ethanol $(0.6: 1 \mathrm{v} / \mathrm{v})$ to remove hemoglobin (Tsuchihashi 1923). Then, $50 \mu \mathrm{l}$ CAT buffer, $100 \mu \mathrm{l}$ sample and $1 \mathrm{ml} 10 \mathrm{mM} \mathrm{H}_{2} \mathrm{O}_{2}$ were added to the samples. Detection was performed at $360 \mathrm{~nm}$. Distilled water was used as a blank probe. SOD activity was determined by the epinephrine method of Misra and Fridovich (1972). A hundred $\mu 1$ lysate and $1 \mathrm{ml}$ carbonate buffer were mixed, and then $100 \mu \mathrm{l}$ of epinephrine was added. Detection was performed at $470 \mathrm{~nm}$.

\section{Determination of glutathion}

The level of reduced glutathione (GSH) was determined based on GSH oxidation with 5.5-dithio-bis6.2-nitrobenzoic acid, using method by Beutler (1975).

\section{Determination of interleukin 6 and tumor necrosis factor alpha}

The serum levels of IL- 6 and TNF- $\alpha$ were measured with a highly sensitive enzymatic immunosorbent assay (ELISA) by rat interleukin kits (R\&D Systems, USA). Before use, the standards were dissolved in phosphate buffered saline ( $\mathrm{pH} 7.2$ ), so that the initial concentrations were $2000 \mathrm{pg} / \mathrm{ml}$. The created stocks were serially seven times twofold diluted in reagent diluents, in order to get a standard curve with seven points. $100 \mu \mathrm{l}$ of work concentration of a capture antibody was poured into the wells of polystyrene microtiter plate (MTP). The plates were sealed, incubated and left overnight at room temperature, after which they were wash buffered. All the samples were dissolved in solvent, in a 1:4 ratio. The dissolved samples and prepared standards were poured into MTP, covered with adhesive foil and left for $2 \mathrm{~h}$ at room temperature. After incubation and rinsing, the well, following an adding of $100 \mu \mathrm{l}$ of work concentration of a detection antibody, were once more covered by adhesive foil and left for another $2 \mathrm{~h}$ at room temperature. After a new incubation and rinsing, Streptavidin-HRP (Streptavidin horseradish peroxidase) was added $(100 \mu \mathrm{l})$. The incubation was interrupted after $20 \mathrm{~min}$ at room temperature, without being exposed to direct sunlight. Following that, $100 \mu \mathrm{l}$ of substrate solution was poured in as well as $50 \mu \mathrm{l}$ of stop solution $\left(2 \mathrm{~N}_{2} \mathrm{SO}_{4}\right)$. The optical density was measured by a microplate reader (Zenyth, Anthos, UK) set at $450 \mathrm{~nm}$ (Crowther 1995).

\section{Statistics}

The statistical analysis was performed using SPSS 19.0 for Windows. Results in Tables and in Figures are expressed as means \pm standard error of the mean. Due to low number of cases, nonparametric tests were used. For difference between unrelated samples Kruskall Wallis and Mann Whitney tests were used, and for difference between related samples Friedman and Wilcoxon test was used. Alpha level for significance was set to $\mathrm{P}<0.05$.

\section{Results}

Although rats were subjected to low, moderate and strenuous swimming training process during 12 weeks, C, MT and OT group did not differ significantly in parameters of cardiac hypertrophy (Table 2), or physical capacity (Table 3). The result on physical capacity test significantly improved in all rats when they were subjected to it for the second time ( $\mathrm{T} 1 \mathrm{vs}$ T2: $\mathrm{P}=0.046$ in $\mathrm{C}$ group, $\mathrm{P}=0.028$ in MT group, $\mathrm{P}=0.043$ in OT group), but no significant difference between any other two successive measurements was observed.

The analysis of venous blood samples of sacrificed rats (Table 4) showed that the only significant difference between groups was in levels of TBARS, whose levels were significantly lower in MT group compared with the $\mathrm{C}$ group $(\mathrm{P}=0.006)$. Levels of other pro/antioxidants $\left(\mathrm{O}_{2}^{-}, \mathrm{H}_{2} \mathrm{O}_{2}, \mathrm{NO}, \mathrm{SOD}, \mathrm{CAT}, \mathrm{GSH}\right)$ were not found to be significantly different between groups. There was no statistically significant difference between groups neither in IL-6 nor in TNF- $\alpha$ level. 
Table 2. Body and heart weight $(X \pm S E)$ of rats.

\begin{tabular}{lcccc}
\hline Parameter & $\begin{array}{c}\text { C group } \\
(\mathbf{n}=7)\end{array}$ & $\begin{array}{c}\text { MT group } \\
(\mathbf{n}=7)\end{array}$ & $\begin{array}{c}\text { OT group } \\
(\mathbf{n}=7)\end{array}$ & Statistics \\
\hline Body weight $(g)$ & $368.33 \pm 14.70$ & $361.66 \pm 14.24$ & $363.33 \pm 9.18$ & $\mathrm{P}>0.05$ \\
Heart weight $(\mathrm{mg})$ & $1566.66 \pm 33.33$ & $1616.66 \pm 65.40$ & $1618.33 \pm 116.66$ & $\mathrm{P}>0.05$ \\
Heart/body weight $(\mathrm{mg} / \mathrm{g})$ & $4.27 \pm 0.14$ & $4.48 \pm 0.15$ & $4.43 \pm 0.25$ & $\mathrm{P}>0.05$ \\
\hline
\end{tabular}

C group - control group, MT group - moderately trained group, OT group - overtrained group.

Table 3. Results $(\mathrm{X} \pm \mathrm{SE})$ of the physical capacity tests.

\begin{tabular}{|c|c|c|c|c|}
\hline Test No. & $\begin{array}{c}\text { C group } \\
(n=7)\end{array}$ & $\begin{array}{l}\text { MT group } \\
\quad(n=7)\end{array}$ & $\begin{array}{l}\text { OT group } \\
(n=7)\end{array}$ & $\begin{array}{c}\text { Two independent } \\
\text { samples test }\end{array}$ \\
\hline$T 1(s)$ & $79.66 \pm 12.65$ & $83.16 \pm 7.80$ & $87.83 \pm 13.26$ & $\mathrm{P}>0.05$ \\
\hline$T 2(s)$ & $141.66 \pm 17.35$ & $159.50 \pm 21.81$ & $160.83 \pm 22.24$ & $\mathrm{P}>0.05$ \\
\hline$T 3(s)$ & $127.33 \pm 18.13$ & $185.00 \pm 12.13$ & $170.50 \pm 17.02$ & $\mathrm{P}>0.05$ \\
\hline$T 4(s)$ & $172.50 \pm 13.40$ & $210.66 \pm 33.36$ & $220.50 \pm 31.14$ & $\mathrm{P}>0.05$ \\
\hline$T 5(s)$ & $132.33 \pm 15.45$ & $200.00 \pm 29.95$ & $214.16 \pm 31.11$ & $\mathrm{P}>0.05$ \\
\hline$T 6(s)$ & $155.83 \pm 21.92$ & $195.50 \pm 19.49$ & $185.50 \pm 27.35$ & $\mathrm{P}>0.05$ \\
\hline Two related samples test & T1 vs T2: $\mathrm{P}<0.05$ & T1 vs T2: $\mathrm{P}<0.05$ & T1 vs T2: $\mathrm{P}<0.05$ & \\
\hline
\end{tabular}

C group - control group, MT group - moderately trained group, OT group - overtrained group.

Table 4. Parameters $(X \pm S E)$ of redox state and inflammation in blood of rats.

\begin{tabular}{lcccc}
\hline Parameter & $\begin{array}{c}\text { C group } \\
(\mathbf{n}=7)\end{array}$ & $\begin{array}{c}\text { MT group } \\
(\mathbf{n}=7)\end{array}$ & $\begin{array}{c}\text { OT group } \\
(\mathbf{n}=7)\end{array}$ & $\begin{array}{c}\text { Two independent } \\
\text { samples test }\end{array}$ \\
\hline $\mathrm{O}_{2}^{-}(\mathrm{nmol} / \mathrm{ml})$ & $9.88 \pm 2.78$ & $14.11 \pm 3.28$ & $12.08 \pm 2.7$ & $\mathrm{P}>0.05$ \\
$\mathrm{H}_{2} \mathrm{O}_{2}(\mathrm{nmol} / \mathrm{ml})$ & $1.36 \pm 0.39$ & $1.42 \pm 0.47$ & $1.23 \pm 0.23$ & $\mathrm{P}>0.05$ \\
$\mathrm{NO}_{2}^{-}(\mathrm{nmol} / \mathrm{ml})$ & $2.67 \pm 0.46$ & $1.9 \pm 0.19$ & $2.13 \pm 0.44$ & $\mathrm{P}>0.05$ \\
$T B A R S(\mu \mathrm{mol} / \mathrm{ml})$ & $0.60 \pm 0.02$ & $0.16 \pm 0.04$ & $0.39 \pm 0.10$ & $\mathrm{C}$ vs $\mathrm{MT}: \mathrm{P}<0.01$ \\
$S O D\left(\mathrm{U} / \mathrm{g} \mathrm{Hbx} 10^{3}\right)$ & $24.42 \pm 8.66$ & $36.63 \pm 14.82$ & $56.98 \pm 15.30$ & $\mathrm{P}>0.05$ \\
$\mathrm{CAT}\left(\mathrm{U} / \mathrm{g} \mathrm{Hb} \times 10^{3}\right)$ & $7.70 \pm 1.28$ & $8.12 \pm 1.65$ & $9.41 \pm 1.88$ & $\mathrm{P}>0.05$ \\
$G S H(\mathrm{nmol} / \mathrm{ml} \mathrm{RBCs})$ & $7816.90 \pm 958.80$ & $7193.35 \pm 2839.92$ & $8756.74 \pm 1549.23$ & $\mathrm{P}>0.05$ \\
$I L-6(\mathrm{pg} / \mathrm{ml})$ & $152.05 \pm 6.46$ & $135.28 \pm 5.48$ & $136.28 \pm 7.99$ & $\mathrm{P}>0.05$ \\
$T N F-\alpha(\mathrm{pg} / \mathrm{ml})$ & $46.84 \pm 10.74$ & $93.16 \pm 20.28$ & $79.83 \pm 17.60$ & $\mathrm{P}>0.05$ \\
\hline
\end{tabular}

C group - control group, MT group - moderately trained group, OT group - overtrained group.

Analysis of prooxidant parameters in the isolated rat heart effluent (Figs 1, 2,3,4) during coronary autoregulation showed that there was no statistically significant difference in levels of any measured parameter between MT and OT groups, while when those groups were compared to $\mathrm{C}$ group, $\mathrm{C}$ group had significantly higher levels of $\mathrm{O}_{2}{ }^{-}$and $\mathrm{H}_{2} \mathrm{O}_{2}$ during periods of specific coronary perfusion pressures.

In case of $\mathrm{O}_{2}^{-}$levels in coronary effluent, following differences were found: 1) $\mathrm{C}$ vs $\mathrm{MT}$ group: $\mathrm{P}=0.028$ during CPP $40 \mathrm{~mm} \mathrm{Hg} ; \mathrm{P}=0.016$ during CPP $60 \mathrm{~mm} \mathrm{Hg}$; $\mathrm{P}=0.028$ during CPP $120 \mathrm{~mm} \mathrm{Hg}$, 2) $\mathrm{C}$ vs OT group: $\mathrm{P}=0.018$ during $\mathrm{CPP} 60 \mathrm{~mm} \mathrm{Hg} ; \mathrm{P}=0.011$ during CPP $80 \mathrm{~mm} \mathrm{Hg}$. 


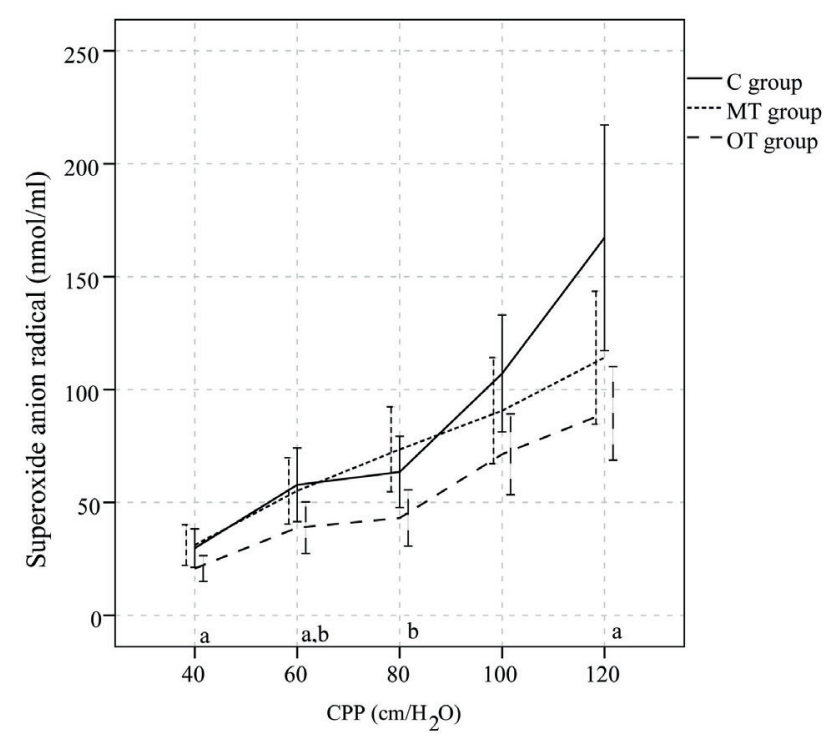

Fig. 1. Values of superoxide anion radical $(X \pm S E \mathrm{nmol} / \mathrm{ml})$ in effluent from an isolated rat heart during different coronary perfusion pressures (a - significant difference between controls $(n=7)$ and moderately trained $(n=7)$ rats, $b$ - significant difference between controls $(n=7)$ and overtrained $(n=7)$ rats, C group - control group, MT group - moderately trained group, OT group - overtrained group).

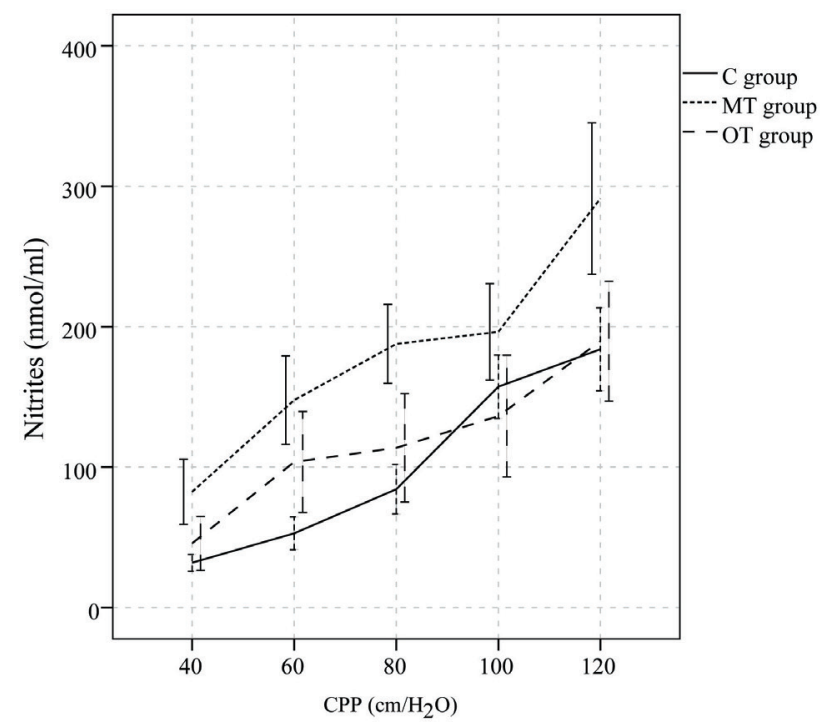

Fig. 3. Values of nitrites $(X \pm S E \mathrm{nmol} / \mathrm{ml})$ in effluent from an isolated rat heart during different coronary perfusion pressures (C group - control group, MT group - moderately trained group, OT group - overtrained group).

Levels of $\mathrm{H}_{2} \mathrm{O}_{2}$ in coronary effluent were found to be significantly different between groups (higher in C group) during following CPP values: 1) $\mathrm{C}$ vs MT group: $\mathrm{P}=0.006$ during CPP $100 \mathrm{~mm} \mathrm{Hg} ; \mathrm{P}=0.004$ during CPP $120 \mathrm{~mm} \mathrm{Hg}$, 2) $\mathrm{C}$ vs $\mathrm{OT}$ group: $\mathrm{P}=0.028$ during CPP $100 \mathrm{~mm} \mathrm{Hg}$.

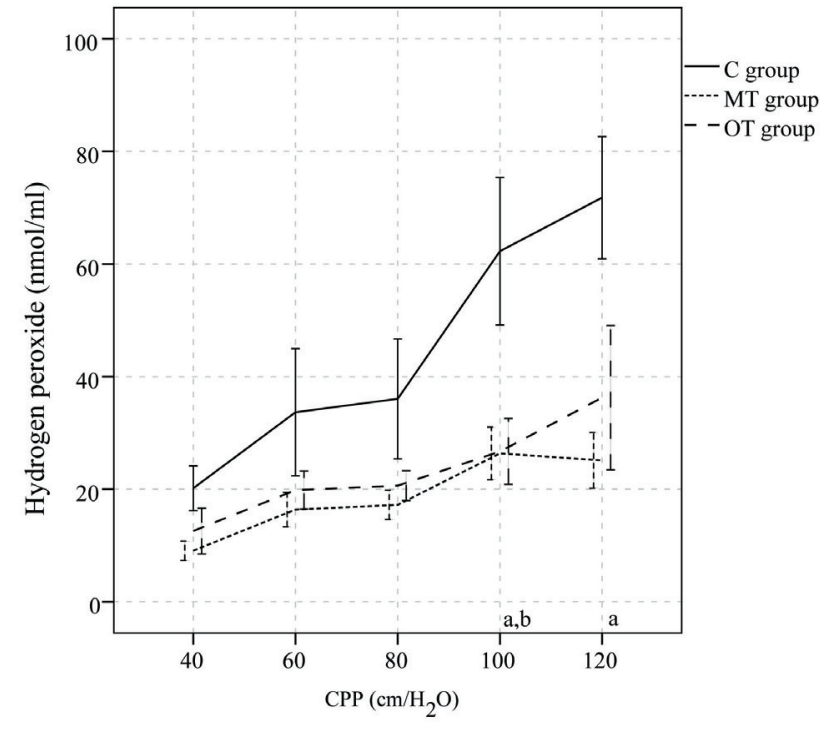

Fig. 2. Values of hydrogen peroxide $(X \pm S E \mathrm{nmol} / \mathrm{ml})$ in effluent from an isolated rat heart during different coronary perfusion pressures $(a-$ significant difference between controls $(n=7)$ and moderately trained $(n=7)$ rats, $b$ - significant difference between controls $(n=7)$ and overtrained $(n=7)$ rats, C group - control group, MT group - moderately trained group, OT group overtrained group).

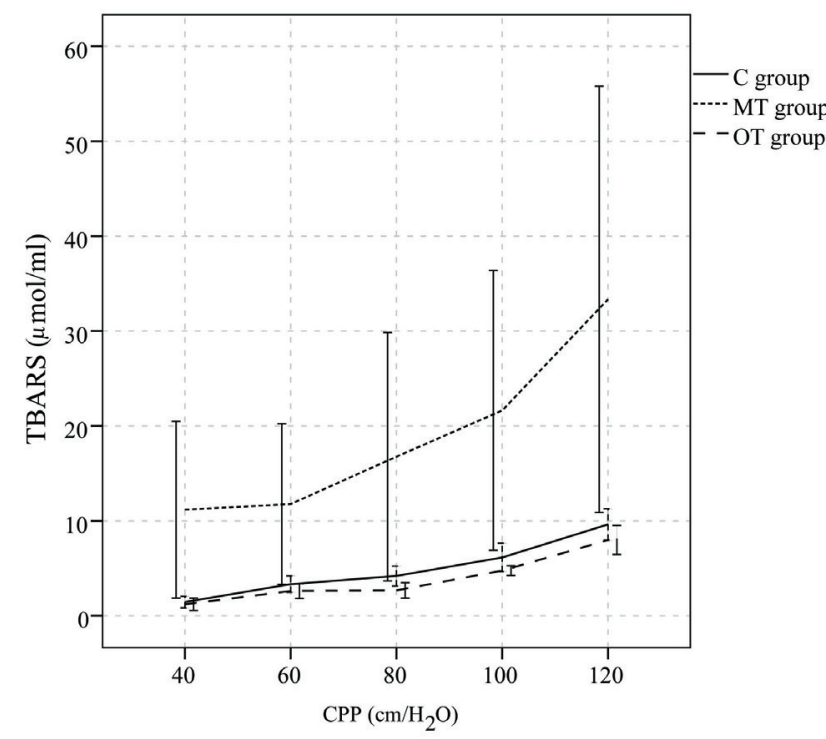

Fig. 4. Values of index of lipid peroxidation $(X \pm S E \mu \mathrm{mol} / \mathrm{ml})$ in effluent from an isolated rat heart during different coronary perfusion pressures (C group - control group, MT group moderately trained group, OT group - overtrained group).

\section{Discussion}

To maximize physical performance, athletes and coaches manipulate training load through adjustments in duration, frequency, and intensity or through a reduction of the regenerative period (Ferraresso et al. 2012). However, if the exercise session lasts too long and 
training sessions are so frequent that they interrupt the recovery phase, the necessary adaptation does not occur (Lehmann et al. 1999). Thus, the aim of our research was to explore the effects of frequent swimming on parameters of oxidative stress and inflammation in blood and isolated heart of rats.

The first aim of the study was to assess the effects of frequent swimming on redox state of rats on both systemic and local level. When analyzing systemic oxidative stress, we measured levels of redox state parameters in venous blood of rats $\left(\mathrm{O}_{2}^{-}, \mathrm{H}_{2} \mathrm{O}_{2}, \mathrm{NO}_{2}{ }^{-}\right.$and TBARS in plasma; GSH levels, SOD and CAT activity in RBCs). The only statistically significant difference between groups that swam according to different training protocols was found in plasma levels of TBARS, which were significantly lower in moderately trained than in the control rats. Measuring TBARS is one of the ways to assess the degree of lipid peroxidation, which is one of the adverse redox change consequences, and their lower levels certainly mean better redox state. Unfortunately, there are no studies that used training protocol similar to ours that explored redox parameters in blood, except that Dong and colleagues (2011) measured malondialdehyde (MDA) levels in overtrained rats blood, and found it significantly increased. However, our overtrained rats experienced no oxidative stress. As the results of physical capacity tests in our study show, the applied frequent swimming training protocol did not induce OTS in rats, so this can explain the absence of adverse redox state in our overtrained rats. Interestingly, although the differences were not shown to be statistically significant, the overtrained rats had the highest levels of all three measured endogenous antioxidants, which is probably the adaptation that occurred in order to cope with increased oxidative demands of multiple daily training sessions. In addition to the data on redox state in blood, as well as on the data on oxidative stress in coronary effluent which will be discussed later, and on recently published data on the cardiodynamics of hearts isolated from rats used in this project (Stojanovic Tosic et al. 2015), it seems that the performed frequent protocol induced desirable changes in both function of the heart and redox state of rats to the equal or even to the greater extent than the moderate, usually performed swimming training regimen. This gives guidelines for future swimming overtraining protocol planning, such as that intensity and maybe volume of a single session, rather than only frequency, must be increased. This hypothesis may be supported by the results of Burneiko and collegues (2004) who showed that, in contrast to the loadless training program, the training program that included swimming with $2 \%$ of rat's body weight was deleterious, increasing both myocardial and plasma oxidative stress.

Endurance exercise training is known to promote beneficial adaptations to numerous tissues including the heart. Many studies have explored the impact of exercise training on myocardial antioxidant capacity, and although there is some inconsistency in results of those studies, there is emerging evidence to suggest that exercise increases antioxidant enzymes in the heart (Powers et al. 2014). The difference between numerous other studies and our study lies in the site where redox parameters were measured. Most studies measured levels of redox state parameters in the whole heart tissue, while we measured levels of prooxidants $\left(\mathrm{O}_{2}^{-}, \mathrm{H}_{2} \mathrm{O}_{2}, \mathrm{NO}_{2}^{-}\right.$and TBARS) in the coronary effluent (we did not measure levels of antioxidants since methods for their estimation require RBCs). Oxidative stress detected this way represent oxidative stress in the endocardium of the left ventricle, although it may also originate from the endothelium of the coronary circulation. Our analysis of prooxidant parameters in the coronary venous effluent during coronary autoregulation on the Langendorf apparatus showed that, compared to the controls, hearts from both moderately trained and overtrained rats produced lower levels of $\mathrm{O}_{2}{ }^{-}$and $\mathrm{H}_{2} \mathrm{O}_{2}$. This is important since it was shown that $\mathrm{O}_{2}^{-}$and $\mathrm{H}_{2} \mathrm{O}_{2}$ induce apoptosis (Chabi et al. 2008) by opening the permeability transition pore and triggering the release of proapoptotic proteins into the cytosol (Jackson et al. 2002). The results of our study cannot directly be compared to other studies that explored the effects of exercise on the myocardium redox state due to different methodology, but it may be said that our results support the hypothesis that, in terms of redox state, moderate exercise exhibits protective effects on the heart muscle.

Levels of cytokines measured in blood of rats subjected to our study protocol did not significantly differ. Average value of IL-6 was somewhat lower in trained rats than in controls, while levels of TNF- $\alpha$ were somewhat increased in trained rats, but the differences were not found to be statistically significant. Thus, our results suggest that moderate intensity training does not induce inflammation in blood of rats. This is in contrast to the study performed by Gholamnezhad and colleagues (2013), who applied training protocol similar to ours and explored levels of cytokines in blood of rats, both in rest and after acute exercise. They found increased IL- 6 and 
TNF- $\alpha$ levels in overtrained rats (compared to controls), both immediately after acute exercise and $24 \mathrm{~h}$ later, and thus concluded that inadequately dosed physical activity induces silent inflammation. Lira and colleagues (2010) also reported the increase of inflammatory cytokines in overtrained rats, but in white adipose tissue.

Finally, the results of our study show that applied frequent swimming protocol, based on previously published running overtraining protocol, was not successful in inducing OTS in rats. This may be the consequence of differences between swimming and running training in rats (Kregel et al. 2006, Seo et al. 2014), or sex differences, since all the studies we compared our results to, used male rats. In most animal studies, females and males differ in the extent of the response to an exercise; thus, the outcomes of a given exercise intervention cannot be generalized for both sexes (Foryst-Ludwig and Kintscher 2013).

\section{Conclusion}

The results of our study add evidence about beneficial effects of regular moderate exercise on blood and cardiac redox state of rats, and furthermore, show that exercising frequently, if the intensity stays within moderate range, may not have detrimental effects, but on the contrary. Further research is needed to discover the elements of the training load that would induce overtraining in rats when using swimming as the chosen physical activity, and thereafter explore the relationship between structure, function and biochemistry of the heart and vascular system in this unexplained phenomenon.

\section{Conflict of Interest}

There is no conflict of interest.

\section{Acknowledgements}

This work was supported by Junior project $08 / 14$ by Faculty of Medical Sciences, Kragujevac, Serbia.

\section{References}

AUCLAIR C, VOISIN E: Nitroblue tetrazolium reduction. In: Handbook of Methods for Oxygen Radical Research. RA GREENWALD (ed.), CRC Press, Ine, 1985, pp 123-132.

BEUTLER E: Reduced glutathione (GSH). In: Red Cell Metabolism, a Manual of Biochemical Methods. E BEUTLER (ed.), Grune and Stratton, New York, 1975, pp 112-114.

BEUTLER E: Catalase. In: Red Cell Metabolism, a Manual of Biochemical Methods. E BEUTLER (ed.), Grune and Stratton, New York, 1982, pp 105-106.

BOCALINI DS, CARVALHO EV, DE SOUSA AF, LEVY RF, TUCCI PJ: Exercise training-induced enhancement in myocardial mechanics is lost after 2 weeks of detraining in rats. Eur J Appl Physiol 109: 909-914, 2010.

BURNEIKO RC, DINIZ YS, FAINE LA, GALHARDI CM, PADOVANI CR, NOVELLI EL, CICOGNA AC: Impact of the training program on lipid profile and cardiac health. Biol Res 37: 53-59, 2004.

CHABI B, LJUBICIC V, MENZIES KJ, HUANG JH, SALEEM A, HOOD DA: Mitochondrial function and apoptotic susceptibility in aging skeletal muscle. Aging Cell 7: 2-12, 2008.

CROWTHER JR: ELISA. Theory and practice. Methods Mol Biol 42: 1-218, 1995.

DONG J, CHEN P, WANG R, YU D, ZHANG Y, XIAO W: NADPH oxidase: a target for the modulation of the excessive oxidase damage induced by overtraining in rat neutrophils. Int J Biol Sci 7: 881-891, 2011.

FAUL F, ERDFELDER E, LANG AG, BUCHNER A: G Power 3: A flexible statistical power analysis program for the social, behavioral and biomedical sciences. Behav Res Methods 39: 175-191, 2007.

FERRARESSO RL, DE OLIVEIRA R, MACEDO DV: Interaction between overtraining and the interindividual variability may (not) trigger muscle oxidative stress and cardiomyocyte apoptosis in rats. Oxid Med Cell Longev 2012: 935483, 2012.

FORYST-LUDWIG A, KINTSCHER U: Sex differences in exercise-induced cardiac hypertrophy. Pflugers Arch 465 : 731-737, 2013.

GHOLAMNEZHAD Z, BOSKABADY MH, HOSSEINI M, SANKIAN M, KHAJAVI RAD A: Evaluation of immune response after moderate and overtraining exercise in Wistar rat. Iran J Basic Med Sci 17: 1-8, 2013.

GREEN LC, WAGNER DA, GLOGOWSKI J, SKIPPER PL, WISHNOK JS, TANNENBAUM SR: Analysis of nitrate, nitrite and [15N] nitrate in biological fluids. Anal Biochem 126: 131-138, 1982. 
HOHL R, FERRARESSO RL, DE OLIVEIRA RB, LUCCO R, BRENZIKOFER R, DE MACEDO DV: Development and characterization of an overtraining animal model. Med Sci Sports Exerc 41: 1155-1163, 2009.

JACKSON MJ, PAPA S, BOLANOS J, BRUCKDORFER R, CARLSEN H, ELLIOTT RM, FLIER J, GRIFFITHS HR, HEALES S, HOLST B, LORUSSO M, LUND E, ØIVIND MOSKAUG J, MOSER U, Di PAOLA M, POLIDORI MC, SIGNORILE A, STAHL W, VIÑA-RIBES J, ASTLEY SB: Antioxidants, reactive oxygen and nitrogen species, gene induction and mitochondrial function. Mol Aspects Med 23: 209-285, 2002.

KADAJA L, EIMRE M, PAJU K, ROOSIMAA M, PÕDRAMÄGI T, KAASIK P, PEHME A, ORLOVA E, MUDIST M, PEET N, PIIRSOO A, SEENE T, GELLERICH FN, SEPPET EK: Impaired oxidative phosphorylation in overtrained rat myocardium. Exp Clin Cardiol 15: e116-e127, 2010.

KREGEL KC, ALLEN DL, BOOTH FW, FLESHNER MR, HENRIKSEN EJ, MUSCH TI, O' LEARY DS, PARKS CM, POOLE DC, RA'ANAN AW, SHERIFF DD, STUREK MS, TOTH LA: Resource Book for the Design of Animal Exercise Protocols. American Physiological Society, Bethesda, 2006, pp 1-80.

LEHMANN M, GASTMANN U, BAUR S, LIU Y, LORMES W, OPITZ-GRESS A, REIBNECKER S, SIMSCH C, STEINACKER JM: Selected parameters and mechanisms of peripheral and central fatigue and regeneration in overtrained athletes. In: Overload, Performance Incompetence, and Regeneration in Sport. M LEHMANN, C FOSTER, U GASTMANN, H KEIZER, JM STEINACKER (eds), Kluwer Academic Plenum, New York, 1999, pp 7-25.

LIRA FS, ROSA JC, PIMENTEL GD, TARINI VA, ARIDA RM, FALOPPA F, ALVES ES, DO NASCIMENTO CO, OYAMA LM, SEELAENDER M, DE MELLO MT, SANTOS RV: Inflammation and adipose tissue: effects of progressive load training in rats. Lipids Health Dis 9: 109, 2010.

MCCORD JM, FRIDOVICH I: Superoxide dismutase an enzymatic function for erythrocuprein (hemocuprein). $J$ Biol Chem 244: 6049-6055, 1969.

MEEUSEN R, DUCLOS M, FOSTER C, FRY A, GLEESON M, NIEMAN D, RAGLIN J, RIETJENS G, STEINACKER J, URHAUSEN A; EUROPEAN COLLEGE OF SPORT SCIENCE; AMERICAN COLLEGE OF SPORTS MEDICINE: Prevention, diagnosis, and treatment of the overtraining syndrome: joint consensus statement of the European College of Sport Science and the American College of Sports Medicine. Med Sci Sports Exerc 45: 186-205, 2013.

MISRA HP, FRIDOVICH I: The role of superoxide-anion in the autooxidation of epinephrine and a simple assay for superoxide dismutase. J Biol Chem 247: 3170-3175, 1972.

OGONOVSZKY H, SASVÁRI M, DOSEK A, BERKES I, KANEKO T, TAHARA S, NAKAMOTO H, GOTO S, RADÁK Z: The effects of moderate, strenuous, and overtraining on oxidative stress markers and DNA repair in rat liver. Can J Appl Physiol 30: 186-195, 2005.

OHKAWA H, OHISHI N, YAGI K: Assay for lipid peroxides in animal tissues by thiobarbituric acid reaction. Anal Biochem 95: 351-358, 1979.

PEREIRA BC, FILHO LA, ALVES GF, PAUli JR, ROPELLE ER, SOUZA CT, CINTRA DE, SAAD MJ, SILVA AS: A new overtraining protocol for mice based on downhill running sessions. Clin Exp Pharmacol Physiol 39: 793-798, 2012.

PICK E, KEISARI Y: A simple colorimetric method for the measurement of hydrogen peroxide produced by cells in culture. J Immunol Methods 38: 161-170, 1980.

POWERS SK, SOLLANEK KJ, WIGGS MP, DEMIREL HA, SMUDER AJ: Exercise-induced improvements in myocardial antioxidant capacity: the antioxidant players and cardioprotection. Free Radic Res 48: 43-51, 2014.

SEENE T, KAASIK P, ALEV K, PEHME A, RISO EM: Composition and turnover of contractile proteins in volumeovertrained skeletal muscle. Int J Sports Med 25: 438-445, 2004.

SEO DY, LEE SR, KIM N, KO KS, RHEE BD, HAN J: Humanized animal exercise model for clinical implication. Pflugers Arch 466: 1673-1687, 2014.

STOJANOVIC TOSIC JT, JAKOVLJEVIC VL, ZIVKOVIC VV, SREJOVIC IM, VALDEVIT ZJ, RADOVANOVIC DS, DJURIC DM, AHMETOVIC ZK, PERIC DB, CANKOVIC MB, JOVANOVIC MS, DJORDJEVIC DZ: Biphasic response of cardiodynamic adaptations to swimming exercise in rats. Gen Physiol Biophys 34: 301-310, 2015.

TSUCHIHASHI M: Zur Kernntnis der blutkatalase. Biochem Z 140: 65-72, 1923. 
ZOPPI CC, MACEDO DV: Overreaching-induced oxidative stress, enhanced HSP72 expression, antioxidant and oxidative enzymes downregulation. Scand J Med Sci Sports 18: 67-76, 2008. 